\title{
PELATIHAN MOZAIK BAGI SISWA-SISWI DI SMP MUHAMMADIYAH PADANGPANJANG
}

\author{
Alipuddin'), Ranelis ${ }^{1)}$, Rahmad Washinton 2) \\ 1)Program Studi Pendidikan Kriya, Fakultas Seni Rupa Dan Desain, ISI Padangpanjang, Padangpanjang, \\ Sumatera Barat, Indonesia \\ 2)Program Studi Kriya Seni, Fakultas Seni Rupa Dan Desain, ISI Padangpanjang, Padangpanjang, \\ Sumatera Barat, Indonesia \\ Corresponding author : Alipuddin \\ E-mail : alipuddinisipp@gmail.com
}

Diterima 25 November 2021, Direvisi 11 Desember 2021, Disetujui 11 Desember 2021

\begin{abstract}
ABSTRAK
Pengabdian Kepada Masyarakat Dengan Judul "Pelatihan Mozaik Bagi Siswa-Siswi Di Smp Muhammadiyah Padangpanjang" ini bertujuan supaya siswa dan siswi di SMP Muhammadiyah Padangpanjang mampu untuk membuat benda kerajinan berupa hiasan dinding dengan teknik mozaik. Mozaik merupakan sebuah teknik dalam seni dekorasi dan juga merupakan aspek dari dekorasi interior. Sasaran dari kegiatan pengabdian ini adalah siswa dan siswi SMP Muhamadiyah Padang Panjang Sumatera Barat. Pelatihan ini dilakukan dengan dua metode yaitu metode ceramah dan metode demonstrasi. Metode ceramah dilakukan dengan cara memberikan penjelasan kepada siswa dan siswi di SMP Muhammadiyah Padangpanjang tentang apa itu mozaik, bahan dan alat yang digunakan dalam pembuatan mozaik. Memberikan penjelasan kepada siswa dan siswi bagaimana membuat karya dengan memanfaatkan bahan alam yang ada disekitar lingkungan mereka untuk dijadikan karya seni berupa hiasan dinding. Metode demontrasi dilakukan dengan cara praktek langsung bagaimana proses pembuatan produk dengan teknik mozaik berupa hiasan dinding. Kegiatan ini dimulai dengan penyedian alat dan bahan untuk mozaik seperti daun-daunan, ranting, serbuk ketem dan lain-lain Hasil yang dicapai dari kegiatan pelatihan mozaik ini adalah hampir semua siswa dan siswi mampu memahami apa itu teknik mozaik dan mereka mampu untuk membuat hiasan dinding dengan teknik mozaik dengan bentuk dan motif yang berbeda-beda antara satu anak dengan anak yang lain sehingga memiliki nilai keindahan tersendiri bagi orang yang melihatnya..
\end{abstract}

Kata kunci: mozaik; bahan; lingkungan; hiasan dinding .

\begin{abstract}
This Community Service with the title "Mosaic Training for Students at SMP Muhammadiyah Padangpanjang" aims to enable students at SMP Muhammadiyah Padangpanjang to be able to make handicrafts in the form of wall hangings with the mosaic technique. Mosaic is a technique in the art of decoration and is also an aspect of interior decoration. The target of this service activity is the students of SMP Muhammadiyah Padang Panjang, West Sumatra. This training was conducted using two methods, namely the lecture method and the demonstration method. The lecture method is carried out by giving explanations to students at SMP Muhammadiyah Padangpanjang about what a mosaic is, the materials and tools used in making a mosaic. Provide an explanation to students and students how to make works by utilizing natural materials that are around their environment to be used as works of art in the form of wall decorations. The demonstration method is carried out by direct practice how the process of making products with mosaic techniques in the form of wall hangings. This activity begins with the provision of tools and materials for mosaics such as leaves, twigs, ketem powder and others. The results achieved from this mosaic training activity are that almost all students are able to understand what a mosaic technique is and they are able to make wall decorations. with a mosaic technique with different shapes and motifs from one child to another so that it has its own beauty value for people who see it.
\end{abstract}

Keywords: mosaic; material; environment; wall decoration.

\section{PENDAHULUAN}

Pengabdian yang berjudul Pelatihan Mozaik Bagi Siswa dan Siswi Di SMP Muhamaddiyah kota Padangpanjang ini adalah berupa pelatihan mozaik. mozaik adalah seni menciptakan gambar dengan menyusun kepingan-kepingan kecil berwarna dari kaca, batu, daun atau bahan lain. Seni mozaik ini 
merupakan sebuah teknik dalam seni dekorasi dan juga merupakan aspek dari dekorasi interior (Nurharini \& Widihastrini, 2020). Seni mozaik merupakan seni berkarya yang menuntun kepekaan dengan memanfaatkan benda yang ada di lingkungan, yang pada awalnya tidak dimanfaatkan atau digunakan, menjadi benda yang dapat digunakan (Hasnawati \& Anggraini, 2018). Menurut Hajar Pamadhi (2008 : 5.6) definisi metode mozaik yaitu pembuatan karya seni rupa dua dimensi atau tiga dimensi yang menggunakan material atau bahan dari kepingan-kepingan yang sengaja dibuat dengan cara dipotong-potong yang kemudian disusun dengan cara ditempelkan pada bidang datar dengan cara dilem. Pemanfaatan biji-bijian masih jarang dilakukan oleh masyarakat, namun sudah ada juga beberapa orang yang menjadikan sebuah karya seni yang memiliki nilai ekonomis. Menurut Mulyono (2007 : 4), biji-bijian dapat dimanfaatkan dalam kegiatan berkarya seni. Biji-bijian digunakan sebagai bahan utama dalam pembuatan hiasan dinding, rumah miniatur, kanvas, souvenir, dan sebagainya. Demikian halnya dengan Erman dan Ismiatun (2004 : 8) yang menjadikan biji- bijian sebagai bahan dalam membuat rangkaian bunga, kotak tisu, boneka, dan lain-lain. (Harni \& Yunisrul, 2018) Kegiatan berkarya seni menempel ini merupakan media ekspresi karena anak- anak secara individual dan naluriah akan dapat mengungkapkan ide dalam bentuk yang indah. Terdapatnya unsur-unsur seni rupa tempel seperti garis, warna, bentuk dan tekstur merupakan bukti adanya aktualisasi ideide/gagasan, imajinasi, pengalaman yangestetisyang kemudian diungkapkan berwujud ekspresi simbolis yang sangat pribadi Begitupun dengan pelatihan yang penulis berikan bersama tim di SMP Muhamaddiyah Padangpanjang. Pelatihan ini menggunakan bahan daun kering, ranting, biji-bijian, serbuk kayu dan triplek sebagai landasannya. Di samping, bahan tersebut ada bahan lain yang dipakai seperti lem kayu sebagai perekat dan kayu propil sebagai pigura dan cat minyak. Alat yang digunakan dalam pelatihan ini adalah alat tulis untuk mendesain dan tidak kalah pentingnya alat pemotong yaitu gunting dan pisau cutter.

(Nurharini \& Widihastrini, 2020) fungsi siswa mempelajari materi ini adalah: 1). Fungsi praktis , yaitu fungsi pada benda sehari-hari, karya tersebut dapat digunakan sebagai bahan dekorasi, 2). Fungsi edukatif, yaitu dapat membantu

mengembangkan daya pikir, daya serap, emosi, estetika, dan kreativitas, 3). Fungsi ekspresi, yaitu dengan menggunakan berbagai bahan dan tekstur dapat membantu melejitkan ekspresi, 4). Fungsi psikhologis, yaitu dengan menuangkan ide, emosi yang menimbulkan rasa puas dan kesenangan sehingga dapat mengurangi beban psikhologis, 5). Fungsi sosial, yaitu dapat menyediakan lapangan pekerjaan dengan banyaknya karya yang dimiliki diharapkan dapat menciptakan lapangan pekerjaan dengan modal kreativitas. (Pamadi,2010). Pertanyaan

Pelatihan ini dilakukan dengan dua metode yaitu metode ceramah dan metode demonstrasi. Metode ceramah dilakukan dengan cara memberikan penjelasan tentang membuat mozaik kepada siswa dan siswi SMP Muhammadiyah dengan memanfaat bahan yang ada disekitar lingkungan mereka untuk dijadikan karya seni. Metode demontrasi dilakukan dengan cara bagaimana proses pembuatan produk denganteknik mozaik, yang dimulai dengan penyedian alat dan bahan untuk mozaik seperti daun-daunan, ranting, serbuk ketem dan lain-lain. Produk yang dibuat dalam mozaik ini adalah berupa panel atau hiasan dinding. Produk ini bisa dipajang di ruangan kelas untuk memperindah atau mempercantik ruang kelas.

\section{METODE}

Metode yang digunakan dalam kegiatan pengabdian berupa pelatihan mozaik bagi siswa dan siswi di SMP Muhammadiyah Padangpanjang ini dengan cara metode ceramah dan memberikan pelatihan kepada siswa dan siswi di SMP Muhammadiyah Padangpanjang dengan cara mendampingi mereka pada waktu pelatihan. Proses sosalisai dilakukan dengan langkah-langkah sebagai berikut:

\section{Tahap persiapan}

Tahap persiapan dilakukan dengan cara observasi langsung ke sekolah di SMP Muhammadiyah Padang, mengurus perizinan untuk melakukan pelatihan, dan menyiapkan materi yang akan diberikan kepada peserta pelatihan

\section{Tahap Pelaksanaan}

Tahap pelaksanaan ini dilakukan dengan cara memberikan sosialisai berupa penjelasan kepada siswa dan siswi SMP Muhammadiyah Padangpanjang mengenai apa itu mozaik, bahan, alat, dan produk apa saja yang dibuat dengan teknik mozaik. Memberikan contoh bagaimana cara membuat karya dengan teknik mozaik. Mendampingi siswa dalam pembuatan karya mozaik.

\section{Tahap Evaluasi}

Tahap Evaluasi yang tim penulis lakukan dalam kegiatan pelatihan mozaik bagi siswa dan siswi di SMP Muhammadiyah Padangpanjang ini 
dilakukan untuk melihat sejauh mana siswa dapat memahami tentang mozaik dan membuat karya mozaik yang telah diberikan. Dari Hasil evaluasi terlihat bahwa siswa dan siswi di SMP Muhammadiyah padang panjang mampu membuat karya dengan teknik hiasan dinding dengan teknik mozaik.

\section{HASIL DAN PEMBAHASAN}

Berdasarkan rencana program kegiatan pengabdian kepada masyarakat yang telah ditetapkan sebelumnya, terkait dengan pelatihan Mozaik bagi siswa dan siswi di SMP Muhammadiyah Padangpanjang, maka dilaksanakan melalui beberapa tahapan kerja. Adapun bentuk tahapan kegiatan yang sudah dilaksanakan adalah sebagai:

\section{Tahap sosialisasi.}

Melakukan pendekatan secara humoris dengan peserta pelatihan, agar peserta pelatihan atau siswa dan siswi merasa senang dan semangat untuk melaksakan program ini, sekaligus mensosialisasikan program kegiatan pengabdian dan memberikan arahan berupa motivasi tentang pentingnya penguasaan keterampilan khususnya bagi siswa dan siswi SMP Muhammadiyah Kota Padangpanjang baik itu secara individual maupun berkelompok. Sehingga peserta mengerti maksud dan tujuan dari pelaksanaan kegiatan pengabdian kepada masyarakat ini.

Sebelum melaksanakan praktek terlebih dahulu memberikan pengetahuan dan penjelasan tentang teknik membuat prakarya mozaik, bahan yang digunakan dan alat yang dipakai. Di samping itu, juga menjelaskan cara mendesain mozaik serta penciptaan bendabenda kriya yang kreatif dan inovatif sehingga diminati oleh siswa dan siswi SMP Muhammadiyah Kota Padangpanjang.

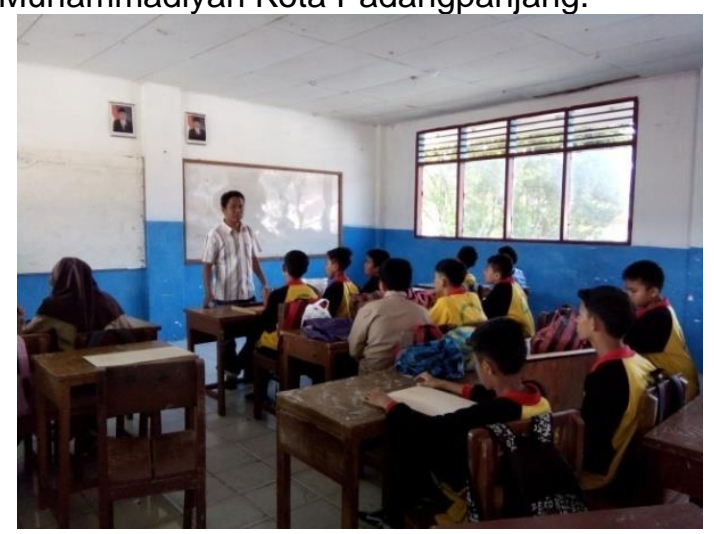

Gambar 1. Mensosialisasikan Program

Kegiatan kepada peserta

(Sumber: Koleksi penulis, 2019)
Di Sekolah Menengah Pertama (SMP) Muhamaddiyah ada materi Seni budaya dan prakarya (SBDP), disana kita melaksanakan pengabdian dengan melatih siswa tersebut atau berkreasi membuat mozaik dekoratif dengan bahan yang digunakan daun--daunan, rantingranting, biji-bijian, serbuk ketam dan sebagainya.

Bahan-bahan tersebut sangat mudah didapat disekitar kita. Sebelum melaksanakan pembuatan mozaik terlebih dahulu disediakan landasan yang digunakan adalah triplek untuk menempel bahan dengan ukuran $30 \times 40$, kemudian meyediakan lem kayu sebagai perekat lalu menyediakan seperti daun-daunan, ranting, serbuk ketam, biji-bijian sesuai dengan desain yang telah direncanakan siswa seperti gambar bunga yang sedang mekar, pemandangan alam, tulisan kaligrafi dan sebagainya.

Setelah menyediakan bahan dan alat, tahap selanjutnya memotong ranting kayu dan mengunting daun-daunan baik yang sudah kering maupun yang masih basah sesuai yang kita inginkan. Kemudian bahan tersebut ditempel dengan menggunakan lem kayu pada tripek sesuai dengan desainnya. Di dalam pembuatan desain diupayakan yang sangat sederhana karena siswa baru pertama mencoba membuat mozaik. Desain tersebut dibuat sesuai pola yang diinginkan supaya memudahkan dalam menempelkan bahan yang digunakan misalkan membuat bunga yang memiliki daun dan tangkai, masing-masing dibuat secara hati-hati dengan penuh kesabaran dan ketelitian.

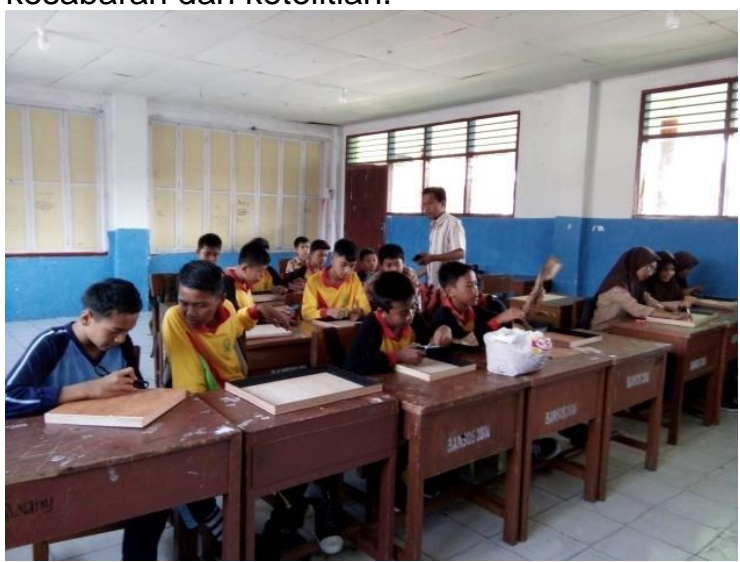

Gambar 2. Pembuatan desain produk mozaik ( Sumber: Koleksi penulis, 2019)

\section{Proses Pelatihan.}




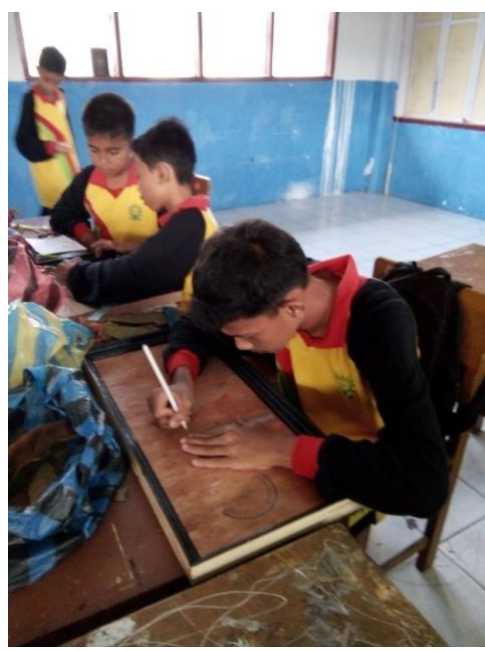

Gambar 3. Pemindahan desain ke kayu atau triplek sebagai bahan dasar

( Sumber: Koleksi penulis, 2019)

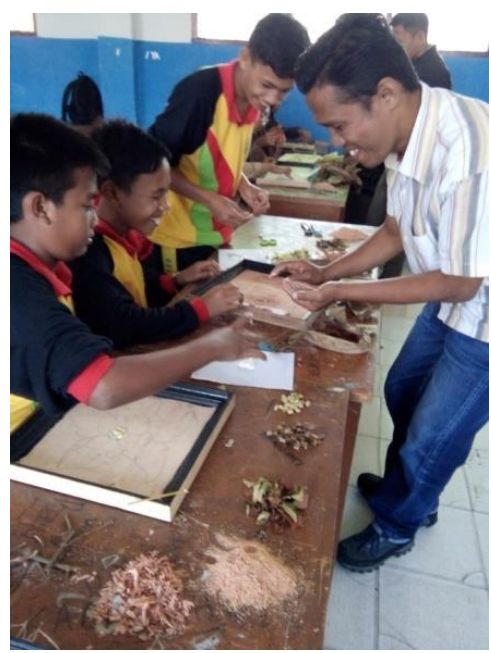

Gambar 4. Mengajar cara penempelan bahan mozaik ke bahan dasar kayu atau triplek

(Sumber: Koleksi penulis, 2019)

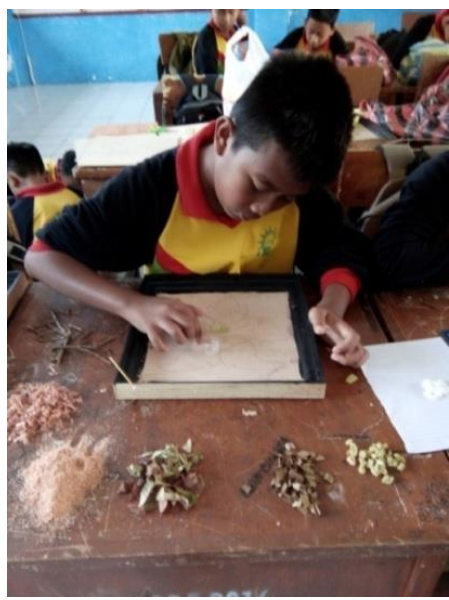

Gambar 5. Penempelan bahan mozaik ke bahan dasar kayu atau triplek

(Sumber: Koleksi penulis, 2019)
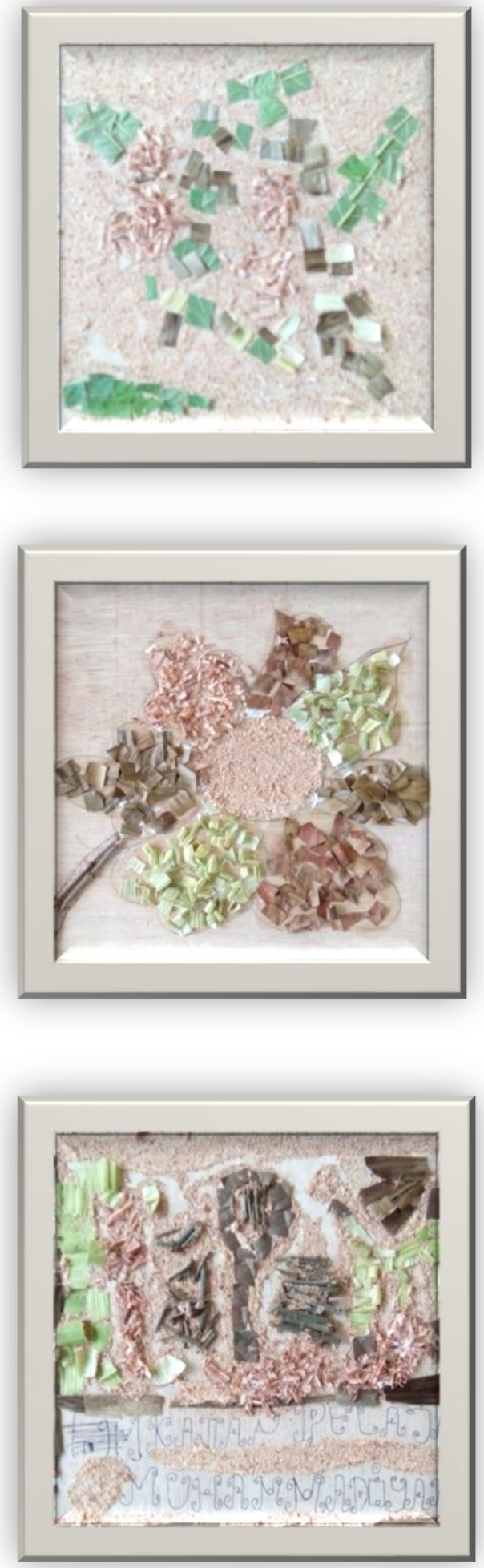

Gambar 6. Karya mozaik yang dihasilkan Siswa dan siswi

(Sumber: Koleksi penulis, 2019)

\section{SIMPULAN DAN SARAN}

Kegiatan pengabdian kepada masyarakat yang dilakukan Pelatihan seni kriya yang diberikan pada dasarnya dilakukan dalam rangka meningkatkan kreativitas bagi siswa 
dan siswi SMP Muhammadiyah. Dengan dilakukannya kegiatan ini mereka telah tahu apa itu mozaik dan mereka mampu membuat hiasan dinding dengan teknik mozaik.

Saran yang dapat penulis berikan adalah diharapkan program pelatihan ini dapat dilaksanakan secara berkesinambungan. Untuk jangka panjang. Diharapkan siswa dan siswi dapat mengembangkan keterampilan mozaik dengan bentuk produk baru yang kreatif dan inovatif.

\section{UCAPAN TERIMAKASIH}

Tim penulis mengucapkan terimakasih kepada kepala sekolah, guru dan murid di SMP Muhammadiyah Padangpanjang, yang tela berpartisipasi dalam program kegiatan pengabdian dalam bentuk pelatihan mozaik pada karya hiasan dinding, sehingga terwujudnya tulisan ini.

\section{DAFTAR RUJUKAN}

Harni \& Yunisrul. (2018). Pelatihan ketrampilan berkarya seni kolase, mozaik, dan montase untuk guru sd. Jurnal Pengabdian Kepada Masyarakat, 1-5.

Hasnawati, H., \& Anggraini, D. (2018). Mozaiksebagai Sarana Pengembangan Kreativitas Anak Dalam Pembelajaran Seni Rupamenggunakan Metode Pembinaan Kreativitas Dan Keterampilan. Jurnal PGSD, 9(2). https://doi.org/10.33369/pgsd.9.2.226235

Nurharini, A., \& Widihastrini, F. L. (2020). Pengembangan Karya Kolase , Montase dan Mozaik Untuk Meningkatkan Kreativitas Guru dalam Pembelajaran SBDP bagi Guru SD. Jurnal Panjar, 2(1), $1-7$. 